\title{
Robert Ślaski
}

Katedra Informatologii i Bibliologii

Uniwersytet Łódzki

e-mail: slaski.robert@gmail.com

\section{「 Tygodnik „Motor” jako najstarsze współczesne polskie czasopismo motoryzacyjne Analiza za lata 1952-1991}

\section{DOI: http://dx.doi.org/10.18778/0860-7435.27.05}

\begin{abstract}
Abstrakt: Tygodnik „Motor" jest najstarszym współczesnym polskim czasopismem motoryzacyjnym. Periodyk w ciągu ponad 65 lat istnienia na stałe wpisał się do kanonu polskiej prasy motoryzacyjnej. Celem prezentowanego tekstu jest przedstawienie losów tytułu, poprzez analizę zmian, którym podlegał, zaczynając od numeru pierwszego z 1952 r. do chwili przejęcia pisma przez nowego wydawcę w 1991 r. Badaniu poddano wybrane roczniki periodyku, zaś część badawczą uzupełniono o próbę analizy teoretycznej i oceny oddziaływania sytuacji politycznej w Polsce w latach 1952-1991 na zawartość treściową i obecność tytułu na rynku prasowym. Do przeprowadzenia badań wykorzystano metodę analizy zawartości prasy oraz metodę historyczną.
\end{abstract}

Słowa kluczowe: prasa motoryzacyjna, prasa PRL, polskie czasopisma motoryzacyjne, tygodnik „Motor”, historia, PRL, transformacja ustrojowa 


\section{Wprowadzenie}

„Motor” jest czasopismem motoryzacyjnym o długim stażu i ugruntowanej przez lata pozycji na polskim rynku prasowym. Początki pisma sięgają lat 50. XX w., a zatem czasów, kiedy wciąż można było dostrzec ślady niedawnej wojny, a motoryzacja powojenna dopiero się kształtowała. Pomimo ponad 65 lat istnienia, tygodnik „Motor” nie doczekał się jeszcze stosownego opracowania. Ponadto zagadnienie dotyczace prasy motoryzacyjnej wydaje się być stosunkowo rzadko przedmiotem badań prasoznawczych ${ }^{1}$. Te dwa powody, a także osobiste zainteresowanie autora tematyką motoryzacji i prasy motoryzacyjnej zdecydowały o próbie podjęcia tematu niniejszego artykułu. Głównym jego celem jest próba przedstawienia historii istnienia czasopisma „Motor" w latach 1952-1991, a zatem od powstania tego periodyku do przejeccia go przez nowego wydawcę. Analizie poddano wybrane roczniki czasopisma 2 . Selekcji roczników dokonano w odstępie dwuletnim począwszy od $1952 \mathrm{r}$. (z kilkoma wyjątkami). Tygodnik „Motor” jako najstarsze i przez długi czas jedyne czasopismo motoryzacyjne ukazujące się na polskim rynku prasowym $z$ racji swojej wieloletniej historii zasługuje na opracowanie o charakterze naukowym. Ważnym aspektem artykułu stało się ukazanie wpływu sytuacji politycznej w Polsce w latach 1952-1991 na opisywany tytuł.

Prasa w czasach PRL funkcjonowała według określonych zasad, zgodnych z celami politycznymi PZPR. Była ona, podobnie jak inne środki masowego przekazu, postrzegana i traktowana przez władzę jak narzędzie służące do realizacji polityki partii i oddziaływania na społeczeństwo (Lubiński, 1991, s. 119-140). Szczególnie ciekawe może wydawać się funkcjonowanie w tak specyficznych warunkach prasy specjalistycznej. Jak zatem kształtowały się wówczas losy i zawartość „Motoru”, będącego jednym z najbardziej rozpoznawalnych tytułów tej grupy?

\section{Towstanie „Motoru”}

- Niewielka liczba czasopism o tematyce motoryzacyjnej ukazująca się w okresie PRL była wynikiem centralizacji, upaństwowienia i upolitycznienia prasy. Dystrybucja papieru podlegała ścisłej kontroli, znacznie ograniczono swobodę wydawnicza, wprowadzono także cenzurę. Dodatkowym powodem,

\footnotetext{
${ }^{1}$ Jak wykazała kwerenda, jedyna publikacją naukowa, mająca związek z tematem podjętym w niniejszym artykule, jest tekst Adama Bańdo (2015), w którym autor uznaje „Motor” za jedyne czasopismo motoryzacyjne epoki PRL (zob. s. 11-13).

2 Analizie poddano następujące roczniki: 1952-1954, 1956-1960, 1962, 1965, 1967-1968, 1970, 1972, 1975, 1977, 1979-1980, 1982-1985, 1987-1991.
} 
który nie sprzyjał popularyzacji prasy motoryzacyjnej, był system sprzedaży pojazdów produkowanych w Polsce, które podlegały reglamentacji (samochód można było kupić jedynie w sprzedaży talonowej). Wymienione wyżej czynniki sprawily, że oficjalne rozwijanie zainteresowania motoryzacja w okresie PRL było obecne jedynie w rubrykach innych czasopism oraz jednego, flagowego tytułu (Bańdo, 2015, s. 12-13).

Tytułem tym jest tygodnik „Motor”, którego pierwszy numer ukazał się dnia 2 kwietnia 1952 r. Periodyk wydawany był w Warszawie, poczattowo przez Wydawnictwa Komunikacyjne, od 1968 r. nakładem Wydawnictwa Komunikacji i Łączności, a następnie od 1974 r. przez Robotniczą Spółdzielnię Wydawniczą „Prasa-Książka-Ruch”. Okładka pierwszego numeru pozostawała w zgodzie z panującym wówczas socrealizmem, przedstawiała zdjęcie robotnika - przodownika pracy z Polskiej Komunikacji Samochodowej na tle autobusu. Czasopismo oficjalnie miało podtytuł sugerujący, że jest pismem fachowym: „tygodnik pracowników transportu samochodowego: organ Związku Zawodowego Pracowników Transportu Drogowego i Lotniczego i Polskiego Związku Motorowego" (Do Caytelników, 1952, s. 1).

Jak wykazała analiza, w latach 1952-1956 na łamach periodyku zamieszczano następujące stałe działy i rubryki ${ }^{3}$ : „Głównie dla początkujących”, „Interwencje”, „Kierowcy na start”, „Kto dopomoże?”, „Motor - mała encyklopedia pojazdów”, „Motorsport ze świata”, „Odpowiedzi redakcji”, „Porady”, „Rozrywki umysłowe”, „Ruch drogowy”, „Sygnały z terenu”, „Szarada drogowa”, „Uwaga! Jedzie chuligan”, „W cieniu dolara”, „W świetle reflektoru”, „Zdajemy egzamin na prawo jazdy”. Jak można dostrzec na powyższych przykładach, redakcja pisma koncentrowała się na organizacji i przestrzeganiu zasad ruchu drogowego, propagowaniu właściwych zachowań oraz piętnowaniu niewłaściwych wzorców, opisywaniu wypadków, kolizji i innych zdarzeń drogowych. Pisano również o egzaminach na prawo jazdy czy poradach technicznych dotyczących właściwego użytkowania pojazdów. Publikowano też listy od czytelników zwracających się do redakcji z prośbą o poradę, a także ogłoszenia czytelników poszukujących części zamiennych do swych samochodów. Ponadto w tygodniku drukowano krzyżówki i szarady, encyklopedyczne opisy pojazdów, kroniki, relacje, reportaże z wyścigów, rajdów i innych imprez mieszczących się w granicach sportów motorowych (Motor, 1956).

Tygodnik „Motor” w latach 1952-1956 liczył 15 stron, drukowany był techniką rotograwiurową w dużym, jak na dzisiejsze czasy, formacie A2, na słabym jakościowo papierze. Tytuł miał charakterystyczny i rozpoznawalny

\footnotetext{
3 Tytuły działów i rubryk podano w porządku alfabetycznym.
} 
logotyp: czerwony napis „MOTOR” umieszczony był na przyczepie ciężarówki, za którą jechał motocykl.

Rys. 1. Logo tygodnika Motor w latach 1952-1956

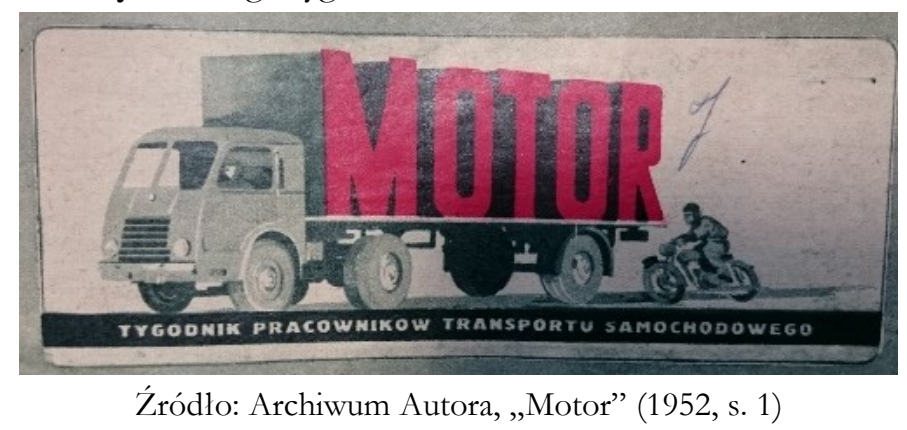

W pierwszych latach istnienia tygodnika druk łącznie z okładkami oraz zdjęciami był czarno-biały ( $\mathrm{z}$ wyjątkiem napisu na logo pisma oraz numeracji i ceny), od 1954 r. zaczęto druk okładek w kolorze. Bardzo często w obrębie jednego numeru można zauważyć nierówną jakość papieru oraz druku. Powodem takiego stanu rzeczy może być reglamentacja papieru, który najprawdopodobniej z racji braków pochodził z odmiennych składów (Motor, 1952-1956).

Cena periodyku kształtowała się początkowo na poziomie jednego ówczesnego złotego (w późniejszych latach stopniowo wzrastała), natomiast nakład pierwszego numeru wynosił około 25 tys. egzemplarzy (Lange, 1959, s. 1). Można ocenić, że (jak na pierwszy numer nowego pisma z dość specjalistycznej i waskiej dziedziny) nakład był bardzo optymistyczny. Nie wiedziano wówczas, jak nowy tygodnik zostanie przyjęty przez czytelników. Wprowadzenie pisma nie było poprzedzane kampania reklamowa, a przepowiadana żywotność „Motoru” oceniana była na okres maksymalnie kilku miesięcy. Jak twierdzili pesymiści, tytuł nie miał dłuższej racji bytu z powodu braków i ubóstwa polskiej motoryzacji początku lat 50. XX w., w związku z czym, jak sądzono, redakcji zabraknie informacji do podejmowania tematyki motoryzacyjnej. W dodatku językoznawcy zgłaszali liczne zastrzeżenia do nazwy nowego czasopisma. Jak pisze redakcja w rocznicowym 400 numerze, „Motor” w założeniu programowym i tematycznym miał wypełnić na rynku prasowym lukę w kwestii informowania polskiego społeczeństwa o obszernie ujętych sprawach motoryzacyjnych, jednak z powodu wymienionych już braków i opóźnień technologicznych polskiej motoryzacji napotykano na nieustannie gromadzące się i rosnące problemy z ustaleniem określonego profilu periodyku (Tamże). 
Pomimo niewróżących sukcesu przewidywań i napotykanych przez redakcję problemów, „Motor” utrzymał się na rynku prasowym, stając się pismem ogólnopolskim, zdobywającym coraz większą liczbę stałych czytelników, powiększającą się z każdym kolejnym numerem. Wzrost popularności pisma prowadził naturalnie do zwiększania jego nakładów, nie było to jednak, jak można się domyślać, proste, $\mathrm{z}$ racji wspomnianych trudności z dostępnością papieru oraz ustalaniem jego ścisłego przydziału. Również dane odnośnie wielkości samych nakładów nie były podawane regularnie i często też niezbyt dokładnie. Świadczyć o tym może sprzeczna liczba nakładu pierwszego numeru wymieniana w numerach jubileuszowych 300 i 400. Pierwszy z nich podaje, że nakład pierwszego numeru nie przekraczał 20 tys. egz., natomiast drugi wymienia liczbę około 25 tys. egz. (Lange, 1958a, s. 1).

Przedstawiając początki „Motoru” nie można również pominąć pewnych zjawisk, właściwości i cech charakterystycznych, które obecne i widoczne były w każdej dziedzinie życia w PRL w pierwszej połowie lat 50. XX w. Te charakterystyczne dla tamtego okresu zjawiska nie ominęły także „Motoru”. Począwszy od pierwszego numeru tygodnika z roku 1952 przez następne kilka lat (do czasu śmierci Józefa Stalina i postępującej następnie odwilży) nieodłącznym elementem czasopisma była polityczna propaganda i socrealistyczna nowomowa, która z „Motoru” (podobnie, jak i z innych tytułów prasowych wówczas wydawanych) uczyniła narzędzie propagandowe ówczesnego kierownictwa PZPR. W niemal każdym wydaniu tygodnika znajdowały się teksty odnoszące się pośrednio lub bezpośrednio do polityki, gloryfikujące socjalizm, PZPR i ZSRR, a krytykujące imperialistów ze „zgniłego” Zachodu, szczególnie Stanów Zjednoczonych, Republiki Federalnej Niemiec czy Francji (Motor, 1952). W numerze pierwszym (1952) już we wstępie od redakcji widoczne sa wspomniane cechy propagandy i nowomowy, co obrazuje poniższy cytat:

„W momencie, gdy amerykańscy imperialiści popełniają zbrodnie ludobójstwa i próbują rozpętać nowa pożogę wojenna, możemy dzięki pokojowemu budownictwu rozpoczać wydawanie nowego tygodnika popularno-technicznego" (Do Caytelników, 1952, s. 1).

Ponadto w redakcyjnym wstępie znajduje się nawiązanie do „Planu sześcioletniego", propagandy sukcesu i charakterystyczny zwrot, w tym przypadku skierowany do czytelników: „Towarzysze i Koledzy”. Krytyka zachodniej myśli technicznej oraz gloryfikowanie motoryzacji radzieckiej miało na celu przekonanie czytelników o wyższości osiagnięć technicznych radzieckich konstruktorów i systemu socjalistycznego nad kapitalistycznym. Przykładem może być krótki, lecz wymowny propagandowy artykuł rysunkowy, zamieszczo- 
ny w numerze 2 (1952) pt. „Komu służy samochód w krajach kapitalistycznych”. Przedstawia on satyryczne rysunki samochodu niemieckiego, amerykańskiego, francuskiego i angielskiego z krótkimi notkami opisującymi w sposób obraźliwy ich właścicieli. Rysunki porównywane są do zamieszczonego zdjęcia radzieckich robotników opuszczających swoimi samochodami fabrykę po skończonym dniu pracy (Komu stu̇̀y samochód..., 1952, s. 9).

\section{Początek odwilży}

L Pod koniec lat 50. XX w. można było zaobserwować odwilż zapoczątkowaną przez śmierć Józefa Stalina. Potwierdzeniem zaprezentowanej tezy może być notka od redakcji z jubileuszowego numeru 300 (1958, s. 1) skierowana do czytelników, w której zespół przyznawał wprost, że w przeszłości popełnił wiele błędów, zaniedbań, niedociagnięć i nie zamierza ich ukrywać. Redakcja zapewniała także, że z każdej popełnionej pomyłki starała się wyciąnąć wnioski na przyszłość. Fragment ten można odczytać jako otwarte przyznanie się do stosowania propagandy i socrealistycznej nowomowy, a także uznanie jej za błędna. Numer 300 został wydany w 1958 r., zatem już w końcowej fazie okresu odwilży zapoczątkowanej i stopniowo postępującej w krajach bloku wschodniego po śmierci Józefa Stalina w 1953 r. Skutkiem odwilży było widoczne w czasopiśmie znaczne złagodzenie języka, zaprzestanie używania nowomowy oraz ograniczenie propagandy i wywyższania na łamach „Motoru" motoryzacji radzieckiej nad zachodnia (Lange, 1958a, s. 1).

Rok 1956 przyniósł zmianę w postaci zrzucenia kamuflażu pisma fachowego. Od numeru 25, który ukazał się w dniu 17 czerwca, podtytuł czasopisma zmieniono z „Motor: tygodnik pracowników transportu samochodowego" na „Motor: tygodnik ilustrowany”. Jak można założyć, zmiana tytułu miała w sposób jawny dowodzić, że periodyk jest adresowany do znacznie szerszego grona odbiorców niż tylko osób zatrudnionych $\mathrm{w}$ transporcie samochodowym. Było to podkreślane przez redakcję w zasadzie od samego początku istnienia pisma, które z założenia miało być „oknem na świat” dla zainteresowanych zaczynająca się wówczas coraz prężniej rozwijać polską i światową motoryzacją oraz techniką (Motor, 1956, s. 12).

W numerze pierwszym z 1957 r. nastapił kolejny ważny element postępującego procesu odmładzania periodyku. Zmianie uległo bowiem logo czasopisma. Dotychczasowe z charakterystycznym napisem na ciężarówce zastapiło nowe, z napisanym nowocześniejszą, większą czcionką głównym członem „Motor”. Można ocenić, że zmiana logotypu tygodnika okazała się dobrym zabiegiem, ponieważ nowy wydawał się bardziej czytelny, dzięki czemu przyciagał wzrok czytelnika. Dodatkowo pod tytułem umieszczono informację 
o nakładzie, który wówczas wynosił 90 tys. egzemplarzy (Lange, 1957, s. 1). Prawdopodobnie, jak można domniemywać, podejmowane zabiegi mające na celu uczynienie pisma atrakcyjniejszym dla odbiorców sprawiły, że cena periodyku wzrosła $z$ wynoszącej wcześniej 1,10 zł do 2,50 zł (Tamże). Za wzrostem ceny czasopisma, a także zmianą tytułu i nowym logo nie podążyła, niestety, poprawa jakości papieru. Nie zwiększono również objętości pisma, która podobnie jak w latach poprzednich wynosiła 15 stron. Również format periodyku nie uległ zmniejszeniu na bardziej poręczny. Zapewne druk pisma na lepszym papierze i w pełnym kolorze był intencja redakcji i wydawcy, lecz z powodu wspominanych już wcześniej narzuconych z góry ograniczeń nie mógł być zrealizowany (Tamże).

Trzeba natomiast podkreślić fakt, że na ile tylko było to możliwe, pojawiały się na łamach „Motoru” kolorowe zdjęcia czy okładki tygodnika. Rozpoczęta w październiku 1956 r. tzw. „odwilż gomułkowska” zdawała się mieć także wpływ na treści publikowane na łamach analizowanego tytułu. Widoczne jest poszerzenie jego tematyki o motoryzację krajów Zachodu, co przejawiało się w druku artykułów dotyczących zachodnich samochodów, dróg czy szeroko pojętej kultury motoryzacyjnej. Teksty niekiedy uzupełniano kolorowymi fotografiami. Co więcej, zdjęcia pojazdów zachodnich zaczęły trafiać na okładki pisma. Patrząc przez pryzmat ówczesnej sytuacji politycznej, jeszcze bardziej zaskakującym może być fakt publikowania w periodyku artykułów na temat amerykańskiej motoryzacji. Prezentowano nowości z amerykańskich szos, nowinki technologiczne stosowane przez producentów. Odnoszono się także do amerykańskiej kultury motoryzacyjnej, która w porównaniu z polską była nieporównywalnie bardziej rozwinięta. Również zdjęcia samochodów „zza wielkiej wody” trafiały na okładki tygodnika. Publikowano też teksty korespondentów i autorów przebywających za granica, jak np. felieton „Piękności, które w 1958 zadebiutują na ekranach”, autorstwa Antoniego Marczyńskiego mieszkającego w Nowym Jorku (Marczyński, 1958, s. 12-13).

Zadając pytanie, czy zmiany wprowadzane w czasopiśmie przez zespół redakcyjny na przestrzeni przeszło 8 lat funkcjonowania tytułu na rynku prasowym były słuszne, należy uwzględnić jeszcze jedna zmienna, poza wymienionymi i omówionymi wcześniej. Otóż elementem, który w sposób istotny uległ zmianie, był nakład tygodnika. Wzrósł on z początkowych 25 tys. egz. tygodniowo (w roku 1952) do ponad 125 tys. egz. tygodniowo (w 1960 roku). Można zatem zaobserwować wzrost nakładu o 100 tys. egz. w ciagu 8 lat, co daje przyrost o 12,5 tys. egz. każdego roku (Lange, 1960, s. 1).

W pierwszych latach istnienia periodyku nie ujawniano informacji o składzie redakcji. Nota redakcyjna zawierała jedynie krótką informację: „,redaguje kolegium”. Pod koniec lat 50. XX w. zaczęto jednak informować czytelników, 
kto zasiada w redakcji „Motoru”. Redaktorem naczelnym pisma był Ryszard Lange, funkcję sekretarza redakcji pełnił Kazimierz Goździewski, za dział publicystyczny odpowiadali Wojciech Babski i Mieczysław Kolbusz, działem kontaktu z czytelnikami zajmowali się Wiktor Bryx oraz Witold Tobis. Z kolei dział sportowy prowadził Stefan Kubiak, a działem technicznym kierowali inżynierowie Tomasz Sobiecki oraz Stanisław Szelichowski. Za opracowanie graficzne odpowiedzialne były Janina Duda i Anna Włodarz, a redaktorem technicznym był Tomasz Dołżkiewicz (Lange, 1958b, s. 15).

Niezwykle cenną inicjatywą redakcji „Motoru” było przeprowadzanie testów motocykli i samochodów, początkowo produkcji polskiej, radzieckiej lub produkcji innych krajów socjalistycznych, a w latach późniejszych również tych wytwarzanych na zachodzie Europy. Artykuły z testów nie pojawiały się w każdym numerze tygodnika. Za przyczynę można uznać problem z dostępnościa pojazdów na rynku krajowym. W latach 60 . XX w. na łamach tygodnika zaczęło pojawiać nieco więcej artykułów z cyklu „Badanie drogowe Motoru". Warte odnotowania jest to, że gdy redakcji udało się już pozyskać pojazd do testu, redaktorzy z działu technicznego sprawdzali i opisywali wszystko bardzo dokładnie. Sprawdzano m. in. pozycję za kierownica, wyposażenie i elementy sterowania, komfort jazdy, zużycie paliwa, hamulce, zwrotność, zdolności transportowe, oświetlenie $i$ wiele innych. Redaktorzy inżynierowie przeprowadzali również pomiary drogowe takich parametrów, jak prędkość maksymalna, przyspieszenie pojazdu i elastyczność. Sporządzano rysunki, wykresy, tabele i dokładne opisy, a wszystko omawiano przystępnym językiem, zrozumiałym dla osób nieposiadających wykształcenia technicznego i inżynieryjnego (Sobiecki, 1967).

\section{Mała stabilizacja}

L Lata 1960-1970 można określić jako czas stagnacji pod względem obecności tygodnika „Motor” na rynku prasowym i braku większych zmian zachodzących w czasopiśmie. W roku 1961 zmieniono nazwę wydawcy z Wydawnictw Komunikacyjnych na Wydawnictwa Komunikacji i Laczności, jednak nie przyniosło to żadnych istotniejszych zmian dla samego tytułu. Periodyk nadal drukowano na słabym jakościowo papierze. Można było mieć zastrzeżenia również do samego druku, który miejscami był niezbyt czytelny. Nierzadkie były przypadki nierównej jakości papieru i druku nawet w obrębie jednego numeru. Dostrzegalne było natomiast przykładanie większej uwagi do poprawy jakości zdjęć pod względem ich wykonania, kadru i pomysłowości. Starano się, aby w miarę możliwości, fotografie publikowane w czasopi- 
śmie były drukowane w kolorze. Najważniejsza zmiana w tym okresie miała miejsce w 1962 r. Dotychczasowego redaktora naczelnego Ryszarda Langego, począwszy od numeru 41, zastapił Leon Rejewski. Druga, mniej przyjemna dla czytelników zmianą, był wzrost ceny pisma z 2,50 zł do 3 zł (Rejewski, 1962, s. 1).

Tematyka artykułów tradycyjnie już obejmowała wiadomości motoryzacyjne z kraju i ze świata, opisy nowych oraz istniejących już modeli samochodów i motocykli, rozwiązań technicznych czy komunikacyjnych (także tych zza oceanu). Publikowano relacje sportowe i artykuły o tematyce turystycznej. Relacjonowano najważniejsze imprezy, targi czy wystawy, jak np. 34 Międzynarodowe Targi Poznańskie (Szelichowski, Sobiecki, 1965). Prezentowano nowe inwestycje drogowe w Polsce i za granica, wśród których były „Autostrada Słońca” we Włoszech (Sędzikowski, 1965, s. 4) i południowy ślimak mostu Poniatowskiego w Warszawie (Rejewski, 1968, s. 1, 3). Zwracano dużą uwagę na niską kulturę jazdy wśród polskich kierowców i znaczną liczbę wypadków drogowych (Babski, 1970, s. 1). Komentowano wprowadzenie Kodeksu Drogowego oraz stosunek kierowców do jego znajomości i przestrzegania (Rejewski, 1965, s. 1). Dostrzegano stale rosnąca ilość samochodów w największych miastach. Z kolei w cyklu „Portrety komunikacyjne naszych miast" przedstawiano, jak wygląda ruch drogowy i rozwiązania komunikacyjne m. in. w dwóch największych ośrodkach miejskich, którymi były wówczas Warszawa i Łódź. W artykule „Gordyjski węzeł” zwracano uwagę, że Łódź pod względem problemów komunikacyjnych wynikających $z$ wad istniejącego układu ulic jest podobna do miast amerykańskich. Z tego też powodu określono godziny szczytu w Warszawie jako „niewinną igraszkę” w porównaniu z Lodzią (Kubiak, 1965, s. 6-7).

Bardzo dużo miejsca w czasie omawianej dekady poświęcono dyskusji na temat przyszłości polskiej motoryzacji, konieczności jej rozwoju i modernizacji. Przekonywano, że rażącym błędem jest niedocenianie i zaniedbywanie spraw motoryzacji (Bodnar, 1962, s. 4). W artykule „Kto zajmie się przyszłością motoryzacji indywidualnej" (Czarski, 1965, s. 1) podkreślono, że zapewnienie podaży samochodów osobowych na rynku możliwe jest przez zwiększenie ich importu lub uruchomienie produkcji w kraju np. poprzez zakup licencji. W tekście zaznaczano, że nikt w Polsce nie podjął się jeszcze wówczas naukowego opracowania problematyki rozwoju indywidualnej motoryzacji, w przeciwieństwie do innych gałęzi transportu (Tamże). 


\section{Nowy model „Motoru”}

Dekada lat 70. XX w. była okresem dużych zmian w polskiej motoryzacji. Można powiedzieć, że zostały one zainicjowane przez wprowadzenie do produkcji Polskiego Fiata 125p. Lata 1970-1979 przyniosły również prawdopodobnie najpoważniejsze przeobrażenia w tygodniku „Motor” od momentu jego powstania. Począwszy od 1973 r. nastapiła zmiana wydawcy pisma, które z dotychczasowych Wydawnictw Komunikacji i Lączności przeszło pod skrzydła Młodzieżowej Agencji Wydawniczej RSW „Prasa-Książka-Ruch”. Następnym krokiem, podjętym również w 1973 r., była zmiana wcześniejszego podtytułu ,tygodnik ilustrowany” na ,ilustrowany magazyn motoryzacyjny". W numerze pierwszym z 1975 r. zaprezentowano po raz pierwszy calkiem nowy model „Motoru”, w którym, jak pisała redakcja, od dawna istniała konieczność wprowadzenia zasadniczej modernizacji. Do głównych problemów należało wynikające $\mathrm{z}$ braku papieru oraz warunków poligraficznych ukazywanie się pisma co dwa tygodnie o zmniejszonej objętości, nieporęczny i przestarzały format, mała i słabo czytelna czcionka. Pojawiały się również opinie, że będący pismem ilustrowanym „Motor” powinien forma przypominać poczytne magazyny. Jak podkreśliła redakcja, dzięki przychylności wydawcy warunki papierowo-poligraficzne uległy znacznej poprawie. Pozwoliło to (począwszy od 1975 r.) na zwiększenie objętości pisma do stałych 20 stron w zmniejszonym formacie, wygodniejszym do czytania np. w podróży czy też w samochodzie. Zmieniano również szatę graficzna pisma w celu uczynienia jej nowocześniejszą i bardziej przystającą do ówczesnych realiów. Zastosowane zmiany spowodowały jednak wzrost kosztów wydawniczych czasopisma, takich jak wydatki na papier oraz usługi drukarskie. Następstwem tego było podniesienie ceny egzemplarza z 3 zł do 5 zł (Rejewski, 1975, s. 1).

Tygodnik po zmianach prezentował się bardziej nowocześnie, stał się też czytelniejszy. Zaczęto drukować również reklamy, przypominające nieco te spotykane w popularnych magazynach. $\mathrm{Na}$ początku każdego numeru publikowano zapowiedzi ważniejszych artykułów, które miały pojawić się w następnym tygodniu. Odświeżony „Motor” zawierał również nowe i przeorganizowane rubryki i działy. Należały do nich ${ }^{4}$ : „Aktualności”, „Bezpieczeństwo ruchu”, „Eksploatacja”, ,Jak usprawnić usługi”, „Krajowy przemysł motoryzacyjny”, „Kwadratura kółek”, „Między nami kierowcami”, „Motocykle”, „Nowości rynkowe”, „Ogłoszenia”, „Opinie motoru”, „Podstawy diagnostyki”, „Praktyka na co dzień”, „Problemy, polemiki, poglądy”, „Sport”, „Świat

\footnotetext{
4 Tytuły działów i rubryk podano w porządku alfabetycznym. Należy podkreślić, że nie wszystkie drukowano systematycznie.
} 
starych samochodów”, „Technika”, „Turystyka”. Mnogość działów i rubryk pozwala dostrzec, jak wiele zagadnień motoryzacyjnych i okołomotoryzacyjnych poruszano na łamach tygodnika.

W roku 1975, kiedy zmieniono model pisma, redaktorem naczelnym był Leon Rejewski, natomiast jego zastępcą Stanisław Szelichowski. Funkcję sekretarza redakcji pełnili Elżbieta Gąsiorkowa i Kazimierz Goździewski, działem sportu i turystyki kierował Bogusław Koperski, fotoreporterem był Julian Lewiński, redaktorem działu eksploatacji Zdobysław Perzyński, działem bezpieczeństwa ruchu drogowego zajmował się Jerzy Pomianowski. Natomiast działem kontaktu z czytelnikami kierował Ignacy Potocki, redaktorem działu techniki i przemysłu był zaś Tomasz Sobiecki, opracowaniem graficznym zajmował się Jan Rakoczy, a redakcję techniczna przejęła Jadwiga Czaplicka. W 1977 r., po 15 latach pracy na stanowisku redaktora naczelnego pisma, na skutek choroby serca zmarł Leon Rejewski. Obowiązki redaktora naczelnego tymczasowo pełnił jego zastępca, Stanisław Szelichowski (1977, s. 19). Od numeru 47 (1977) redaktorem naczelnym „Motoru” został Jerzy Jankowski.

\section{Nowe wyzwania i problemy}

L Jak się zdaje, najbardziej dotkliwy dla czytelników był rozpoczęty w drugiej połowie $1981 \mathrm{r}$. proces wzrostu ceny tygodnika, początkowo z 5 do $10 \mathrm{zl}$, następnie od numeru 1 (1982) koszt ten wzrósł do 20 zł. Był to jednak dopiero początek, bowiem im bliżej końca dekady, tym cena periodyku była coraz wyższa. Nieprzesadne będzie stwierdzenie, że pod koniec lat 80 . XX w. koszt czasopisma wzrastał już nie rokrocznie, ale wręcz z miesiąca na miesiąc. I tak, od połowy 1985 r. „Motor” kosztował 30 zł, od numeru 5 (1987) 40 zł, w marcu 1988 r. było to już 70 zł, a w grudniu 1988 r. cenę podniesiono do 100 zł. Skalę i lawinowe tempo, w jakim rosła cena czasopisma, dobrze obrazuje fakt, że w grudniu 1990 r. „Motor” kosztował już 2 tys. zł. Przyczyn tych wzrostów należy upatrywać w kryzysie gospodarczym i inflacji, która powodowała także podwyższenie kosztów produkcji czasopisma. O każdym kolejnym wzroście ceny czasopisma redakcja informowała czytelników. Początkowo podawano dokładne przyczyny, którymi były podwyżki cen papieru, usług poligraficznych i transportu. Były to zatem czynniki niezależne zarówno od redakcji, jak i wydawcy pisma. Z biegiem czasu ograniczono się do zamieszczania komunikatów o kolejnych wzrostach ceny „Motoru” bez wymieniania dokładnych powodów. Jak można przypuszczać, były one już wszystkim czytelnikom dobrze znane (Jankowski, 1982, s. 1; 1987, s. 1;1988a, s. 1; 1989, s. 1; Borkowski, 1989a, s. 1; 1989b, s. 1; 1990a, s. 1). 
Galopujący wzrost ceny czasopisma nie był jedyną negatywną zmianą dla odbiorców w omawianym okresie. W latach 1980-1981 pogarszająca się sytuacja gospodarcza w kraju wymusiła spadek jakości papieru i druku, a także zmniejszenie objętości tygodnika do 12 stron. W wyniku wprowadzenia stanu wojennego nastapiła kilkumiesięczna przerwa w ukazywaniu się „Motoru” na rynku. Periodyk zniknął z kiosków od grudnia 1981 do 11 kwietnia 1982 r., kiedy to ukazał się kolejny numer. Staraniami redakcji i z poparciem wydawcy przywrócono objętość 16 stron, a nakład zwiększono z 90 do blisko 200 tys. egz. Podkreślano jednak, że nawet tak znaczny procentowo wzrost nakładu nie będzie w stanie zaspokoić popytu na pismo (Jankowski, 1982, s. 1).

Numer 1 z 1982 r. był jednocześnie wydaniem jubileuszowym, ponieważ czasopismo obchodziło wówczas 30-lecie istnienia na rynku. $Z$ tej okazji zdecydowano się uatrakcyjnić zawartość periodyku. Postanowiono wprowadzić zmiany, o które w listach do redakcji wielokrotnie zabiegali czytelnicy. $\mathrm{Na}$ okres wiosny i lata przewidziano kolumnę „Jednym śladem”, przeznaczona dla użytkowników motorowerów i motocykli. Dla osób dopiero rozpoczynających przygodę z motoryzacją wprowadzono cykl „Poradnik nowicjusza”, z poradami przepisów prawnych, informacji z zakresu eksploatacji pojazdów czy bezpieczeństwa ruchu drogowego. Natomiast dla doświadczonych użytkowników samochodów pojawił się cykl „Naprawiamy...”, adresowany do kierowców, którzy podstawowe naprawy pojazdu chcieli wykonywać we własnym zakresie. Nową rubryką dla wszystkich czytelników stał się natomiast „Motorelaks”, który miał pełnić rolę rozrywkowa. Drukowano tu m. in. anegdoty ze świata motoryzacji (Tamże).

Mimo opisywanych wcześniej trudności, w 1985 r. można było dostrzec nieznaczna poprawę jakości druku i papieru, na jakim wydawany był omawiany tytuł. Jednak prawdziwa rewolucja w „Motorze” nadeszła niespełna półtora roku po jubileuszu 35-lecia czasopisma. Wyczekiwane długo i z niecierpliwością zmiany poprzedziła zamieszczona w numerze 37 z 1988 r. zapowiedź:
„Za tydzień: «Moton» w zwiększonej do 24 stron objętości, a w numerze między innymi: kłopoty z przedpłatami, zawrotny awans południowokore- ańskiej motoryzacji, Ford Merkury na dwustronicowym posterze, super- sportowe limuzyny, londyńskie piętrusy. Cena wyższa tylko o 20 zł, prenu- meratorzy nie dopłacają różnicy" (Jankowski, 1988b, s. 1).

Numer 38 z dnia 18 września 1988 r. wydany został w nowej, gruntownie odmienionej szacie graficznej. Zmieniła się okładka, logo czasopisma (wprowadzono duży biały napis „MOTOR” na czarnym tle) i układ działów. Widoczny był również lepszej jakości papier, druk, pojawiło się znacznie więcej kolorowych zdjęć, a objętość pisma zwiększono do 24 stron. Tygodnik po modernizacji szaty graficznej wydawał się prezentować świeżo i nowocześnie, 
jak na ówczesne standardy. W odświeżonym periodyku można było zauważyć następujące działy i rubryki : „Ekologia”, „Historia”, „Jeździmy bezpiecznie”, „Motor ocenia”, „Mój samochód”, „Naprawa”, „Nowości techniki”, „Ogłoszenia”, „Problemy motoryzacji”, „Sport”, „Turystyka”, „Wywiad”, „Z kraju i ze świata". Publikowano również felietony i wywiady. Jak wykazała analiza, niektóre z wyżej wymienionych działów nie pojawiały się w każdym numerze, tak jak bywało to już wcześniej w „Motorze”. Ponadto dużą nowością w periodyku były plakaty, zawierane sporadycznie w wybranych numerach. Przykładowo, w numerze 38 (1988) znajdował się plakat samochodu marki Merkur XR4Ti stworzonej przez Forda na potrzeby USA i Kanady (Jankowski, 1988c, s. 6, 19).

W czasie, gdy periodyk poddano modernizacji, redaktorem naczelnym był Jerzy Jankowski. Natomiast w pełnym składzie redakcji zasiadali: Jerzy Borkowski (zastępca redaktora naczelnego), Witold Borewicz (fotoreporter), Ryszard Cydejko (technika i eksploatacja), Jerzy Dyszy (eksploatacja), Elżbieta Gąsiorkowa (zastępczyni sekretarza redakcji), Andrzej Grzelec (fotoreporter), Adam Grzeszak (dział łączności z czytelnikami), Paweł Kasprzycki (bezpieczeństwo ruchu drogowego), Bogusław Koperski (dział publicystyki), Barbara Krusche (redakcja techniczna), Anna Lityńska (redakcja techniczna), Wiesław Najhajt (usługi motoryzacyjne), Krzysztof Potocki (zastępca sekretarza redakcji), Krzysztof Rybarski (technika, eksploatacja), Wojciech Sierpowski (eksploatacja) oraz Bolesław Stefaniak (zastępca redaktora naczelnego i sekretarz redakcji). Do grona stałych współpracowników należeli natomiast: Zbigniew Drexler (bezpieczeństwo ruchu drogowego), Tomasz Kłossowski (redaktor graficzny), Krzysztof Kucharz (eksploatacja), Tomasz Sobiecki (technika motoryzacyjna), Stanisław Szelichowski (sport) i Bronisław Tumiłowicz (ekonomika przemysłu i transportu). Z dużym prawdopodobieństwem można sądzić, że każdy z członków zespołu redakcyjnego był fachowcem w swojej dziedzinie. Fakt ten nasuwa wniosek, iż tak liczny skład redakcji miał z pewnością niebagatelny wpływ na wartość merytoryczną tygodnika (Jankowski, 1988c, s. 23).

Następne zmiany w czasopiśmie nastapiły odpowiednio w październiku 1989 i w połowie 1990 r. Jerzego Jankowskiego na stanowisku redaktora naczelnego zastapił jego dotychczasowy zastępca, Jerzy Borkowski. W tym okresie doszło też do zmiany podtytułu pisma z ,ilustrowany magazyn motoryzacyjny” na „tygodnik motoryzacyjny” (Borkowski, 1989). „Motor” przeszedł również kolejną metamorfozę, dzięki której 8 lipca 1990 r. ukazał się numer z nowa okładka. Ponownie przekształceniu uległo logo czasopisma,

\footnotetext{
5 Tytuły działów i rubryk podano w porządku alfabetycznym.
} 
którego styl nawiązywał do logotypu sprzed 1988 r. Duży, biały napis „motor” pisany małymi literami, lecz nowocześniejszą czcionką różnił się od poprzedniego stylu. Trudno jest wskazać jednoznaczny powód tej zmiany, ale można sądzić, że wcześniejsze logo mogło zostać uznane za zbyt poważne. W tym samym okresie nastapiło ograniczenie nakładu periodyku z 300 do około 200 tys. egz. (Borkowski, 1990c, s. 23). Z dużą dozą prawdopodobieństwa można sądzić, że powodem zmniejszenia nakładu czasopisma były wymieniane już wielokrotnie trudności występujące na wielu płaszczyznach, rozpoczynając od kryzysu gospodarczego i zmian ustrojowych, a kończąc na problemach z restrukturyzacją RSW (Tamże).

Redakcja starała się, na ile było to możliwe, rekompensować czytelnikom ciąłłe podwyżki ceny „Motoru”. Jednym z elementów takiej rekompensaty była omawiana wcześniej modyfikacja działów, które starano się wypełniać wartościowymi i ciekawymi artykułami. Kolejnym czynnikiem mającym nieco osłodzić ciagłe podwyżki cen stały się sporadycznie dodawane do czasopisma plakaty. Za trzeci element należy uznać organizowanie konkursów z nagrodami. W jednym z konkursów, zorganizowanym w 1990 r., nagroda główną był Polski Fiat 126p (popularny „Maluch”) po modernizacji. Starano się, by nagrody w organizowanych konkursach były tak atrakcyjne, jak umożliwiały to zasoby finansowe redakcji (Borkowski, 1990b).

Autorzy artykułów publikowanych w omawianym okresie w pewnym stopniu poruszali podobne kwestie, jak w poprzednio analizowanej dekadzie. Jednak coraz więcej uwagi poświęcano również takim zagadnieniom, jak rosnąca liczba wypadków drogowych, problemy z realizacją przedpłat na samochody (Sobiecki, 1983, s. 3; Grzeszak, 1988, s. 4), reglamentacja paliwa wraz z jego ograniczoną dostępnością (Najhajt, 1984, s. 4), prowadzenie pojazdów pod wpływem alkoholu (Tumiłowicz, 1985, s. 4), ubezpieczenia komunikacyjne i trudności w parkowaniu w dużych miastach (Drexler, 1985, s. 6-7). Czytelnicy mogli także znaleźć w „Motorze” publikacje dotyczące turystyki, jak np. zwiedzanie krajów nadbałtyckich (Dyszy, 1988, s. 18), problemy $\mathrm{z}$ traktowaniem polskich turystów w innych krajach europejskich (Karpińska, 1989, s. 5), wypoczynek nad Zalewem Zegrzyńskim (Olchowik, 1990, s. 16-17) czy wakacje we Włoszech (Karpińska, 1990, s. 16-17).

Jak powszechnie wiadomo, przełom lat 80. i 90. XX w. był w Polsce okresem zmian politycznych, gospodarczych, a także społecznych. Również na łamach „Motoru” poruszano kwestie i obawy związane z polityką gospodarcza, przede wszystkim obejmująca przemysł i rynek motoryzacyjny (Chmielewski, 1989b, s. 2). Zastanawiano się na przykład, jak będzie wyglądała przyszłość Fabryki Samochodów Osobowych znajdującej się na warszawskim Żeraniu (Gawuć, 1989, s. 16-17). Relacjonowano i opisywano niekoń- 
czące się koło spekulacji, domysłów, przeciagających się negocjacji i rozmów dotyczących poszukiwania partnera bądź też całkowitego przejęcia żerańskiej fabryki przez inna firmę (Jankowski, 1988d, s. 2; Grzeszak, 1989, s. 2; Gawuć, 1989, s. 16-17; Borkowski, 1990d, s. 2; Czechowski, 1990, s. 4). Wśród tematów podejmowanych na przełomie dekad był też stan polskich rafinerii (Chmielewski, 1989a, s. 4).

Zbliżający się koniec dekady lat 80. XX w. był dla wydawcy „Motoru” równie trudny, jak dla przedstawicieli pozostałych gałęzi gospodarki PRL. Znaczny spadek zainteresowania oficjalnymi tytułami prasowymi doprowadził do zmniejszenia sprzedaży oraz nakładów. Efektem był deficyt, a w 1983 r. strata 917 mln zl, która przynosiły 123 spośród wszystkich 259 tytułów prasowych wydawanych przez RSW „Prasa-Książka-Ruch”. W 1988 r. do 124 ze wszystkich 276 czasopism trzeba było dopłacać 5 mld zł (Leszkowicz, 2015). Papier, w PRL ściśle reglamentowany, stał się jeszcze trudniej osiagalny. Z tego powodu w sierpniu 1989 r. druk tygodnika „Motor” został wstrzymany na dwa tygodnie. Obrady Okragłego Stołu i załamanie dotychczasowego układu politycznego wymusiły na kierownictwie RSW dogłębną restrukturyzację. Proces ten został zakończony 22 marca 1990 r. uchwaleniem przez sejm „Ustawy o likwidacji Robotniczej Spółdzielni Wydawniczej „Prasa-Książka-Ruch” i powołaniem przez premiera rządu Komisji Likwidacyjnej (Tamże). Jak można sądzić, likwidacja majątku tak rozbudowanego monopolisty wydawniczego, jak RSW nie należała do zadań łatwych. Prowadziło to do wielu perturbacji, które nie ominęły również „Motoru”. W 1991 r. periodyk zniknął z rynku na 42 tygodnie. Jak tłumaczyła redakcja, Komisja Likwidacyjna pomimo ustawowo zagwarantowanej możliwości przejęcia czasopisma przez dotychczasowy zespół odrzuciła wniosek redakcji o przejęcie, proponując udzial w przetargu. Wstępna wycena periodyku przekraczająca ówczesne 2 mld zł była jednak zbyt wysoka w stosunku do możliwości utworzonej przez dotychczasową redakcję spółdzielni Auto Motor Press. Wobec tego redakcja „Motoru” stworzyła nowy tygodnik pt. „Auto Motor Sport”, który przez kilka następnych lat konkurował z „Motorem” (Borkowski, 1991a; 1991b; Kasprzycki, 1991).

Dnia 7 grudnia 1991 r. „Motor” pod skrzydłami wydawnictwa Labor i z częściowo nowym zespołem redakcyjnym, którym kierował Paweł Kasprzycki, powrócił do kiosków. Po raz kolejny zmieniono również podtytuł czasopisma. Wówczas brzmiał on „magazyn motoryzacyjny” (Kasprzycki, 1991). Periodyk przetrwał zatem zawirowania związane z likwidacją RSW i po trwającej 42 tygodnie przerwie ukazal się na wciąż jeszcze nie do końca ukształtowanym w nowym ustroju rynku prasowym. Atuty czasopisma, takie jak duża rozpoznawalność i wypracowana wcześniej pozycja pozwalały przypuszczać, że najgorszy czas tytuł miał już za sobą i poradzi sobie z dostosowaniem do nowych realiów. 


\section{Podsumowanie}

L Założyć można, że popularyzacja oraz rozwijanie zainteresowania motoryzacją zwłaszcza tą indywidualną, wśród społeczeństwa nie była w zgodzie z ówczesnym programem kierownictwa PZPR. Co więcej, posiadanie samochodu było w PRL oznaką wyższego statusu w społeczeństwie i kłóciło się z oficjalną linia partii. Jednak pomimo wszelkich trudności i niechęci ze strony władzy w 1952 r. doszło do pojawienia się na rynku prasowym tygodnika „Motor”. Chociaż podtytuł sugerował, że czasopismo ma charakter fachowy, w rzeczywistości było ono jednak tytułem o charakterze popularnym. Wbrew trudnościom i obawom, że takie czasopismo się nie przyjmie i jest zbędne, „Motor” odniósł sukces i zyskał uznanie wielu czytelników. Nie przeszkodziła mu w tym nawet stosowana nachalnie w latach 50 . XX w. propaganda polityczna i socrealistyczna nowomowa.

Nieprzesadne będzie stwierdzenie, że „Motor” był swego rodzaju „barometrem" pokazującym nastroje oraz sytuację polityczną w kraju. W czasach odwilży, rozpoczętej przez Wiesława Gomułkę, w czasopiśmie nastapiła zmiana w postaci modernizacji logotypu, poprawy druku, a także tematyki artykułów pojawiających się na jego łamach. Czytelnicy mogli dowiedzieć się o światowych nowościach motoryzacyjnych, kulturze jaka panowała wśród zachodnich kierowców, rozwiązaniach komunikacyjnych, międzynarodowych targach motoryzacyjnych czy wyprawach turystycznych. Co ciekawe, tematyka ta dotyczyła także Stanów Zjednoczonych. Szerokim uznaniem cieszyły się przeprowadzane przez redakcję tygodnika testy pojazdów zwane badaniami drogowymi. Z biegiem lat w „Motorze” zmieniał się także zespół redakcyjny. Do 1989 r. pismem kierowało trzech redaktorów naczelnych, a najdłużej funkcję tę sprawował Leon Rejewski, który przez 15 lat uczynił z periodyku swoisty przewodnik po świecie motoryzacji. Kiedy rozpoczął pełnienie funkcji redaktora naczelnego, w czasopiśmie o dziennikarzy motoryzacyjnych było niezwykle trudno, dlatego też Leon Rejewski sam kształcił poszczególnych redaktorów. Rządy Edwarda Gierka przyczyniły się do znaczącej przemiany „Motoru”, którego wydawcą została Młodzieżowa Agencja Wydawnicza RSW „Prasa-Książka-Ruch”. Czasopismo zyskało nową szatę graficzną, logo, format, poprawiono jakość papieru, pojawiły się nowe działy i rubryki, zmienił się też podtytuł pisma.

Dekada lat 80. i początek lat 90 . XX w. nie były łatwe dla społeczeństwa polskiego. Stan wojenny, kryzys gospodarczy czy zmiana ustroju politycznego powodowały wiele trudności. Borykała się z nimi również redakcja „Motoru”, którego cena na skutek kryzysu rosła w znacznym tempie. Kolejnymi problemami były braki papieru, słaba jakość druku oraz niewystarczający, jak na zapotrzebowanie, nakład pisma. $Z$ powodu wprowadzenia stanu wojennego 
czasopismo, podobnie jak większość periodyków w tym czasie, nie ukazywało się przez kilka miesięcy. W 1982 i 1987 r. omawiany tytuł obchodził odpowiednio 30 i 35 jubileusz od daty ukazania się pierwszego numeru. Okazje te przyczyniły się do modyfikacji i zwiększenia atrakcyjności treściowej czasopisma zgodnie z napływającymi listownie sugestiami czytelników. Starania redakcji i wydawcy zaowocowaly w 1988 r. wprowadzeniem obszernej modernizacji w czasopiśmie, które otrzymało nową szatę graficzną wraz z okładką i logo. Zwiększono również objętość periodyku, pojawiły się nowe działy i rubryki. Sposobem na rekompensatę za drożejące czasopismo stały się dodawane do czasopisma sporadycznie plakaty oraz organizowane przez redakcję konkursy z nagrodami. Rok 1989 r. przyniósł zmianę na stanowisku redaktora naczelnego, którym został Jerzy Borkowski. W tym okresie zmienił się również podtytuł pisma. Kolejna zmiana w szacie graficznej nastapiła w 1990 r., kiedy redakcja zaproponował nową okładkę oraz logo, przypominajace swoim krojem to $\mathrm{z}$ lat 80 . XX w. W podejmowanej na łamach pisma problematyce dużo uwagi poświęcano problemom dotyczącym przedpłat za pojazdy, dostępności benzyny, ubezpieczeń komunikacyjnych czy braku części zamiennych do samochodów. Pisano także o motoryzacji zagranicznej, międzynarodowych plebiscytach, nowościach modelowych, a także samochodach sportowych. Dużo miejsca poświęcano na zagadnienia związane z przyszłościa polskiej motoryzacji w okresie postępującego kryzysu i przemian gospodarczych. Na początku lat 90 . XX w. redakcja zmagała się z trudnościami, wynikającymi z likwidacją dotychczasowego wydawcy „Motoru”, czyli koncernu prasowego RSW „Prasa-Książka-Ruch”. Spółdzielnia, założona przez dotychczasową redakcję czasopisma, nie zdołała uzyskać praw do wydawania tygodnika, wobec czego postanowiono założyć nowe czasopismo motoryzacyjne („Auto Motor Sport”). Przez kilka kolejnych lat obydwa tytuły konkurowały ze soba. „Motor” powrócił do kiosków po 42 tygodniowej nieobecności pod szyldem wydawnictwa Labor.

Przedstawione w niniejszym tekście dzieje czasopisma „Motor” dokumentuja i porządkuja prawie 40 lat historii tego tytułu. Ponadto w pewnym stopniu ukazują silny wpływ sytuacji politycznej i gospodarczej w Polsce w latach 1952-1991 na wybrane elementy związane z funkcjonowaniem tygodnika (jak np. jego treść, szata graficzna, nakład, cena oraz objętość). Zarówno ewolucja periodyku, jak i zachodzace w nim na przestrzeni lat zmiany dowodzą, że stosunek PZPR do środków masowego przekazu mial swoje odzwierciedlenie również w omawianym czasopiśmie. 


\section{Bibliografia}

Babski, Wojciech (1970). Czy milicja się czepia? Motor: tygodnik ilustrowany, 48, 1.

Bańdo, Adam (2015). Polskie czasopisma motoryzacyjne do 1989 roku. Gospodarka Rynek. Edukacja, 1, 5-14.

Bodnar, Artur (1962). Samochód-współpraca-samochód. Motor: tygodnik ilustrowany, 32.

Borkowski, Jerzy (1989a). Motor: ilustrowany magazyn motoryzacyjny, 40, 1.

Borkowski, Jerzy (1989b). Motor: tygodnik motoryzacyjny, 45, 1.

Borkowski, Jerzy (red.) (1989). Motor: ilustrowany magazyn motoryzacyjny, 40.

Borkowski, Jerzy (red.) (1990a). Motor: tygodnik motoryzacyjny, 6, 1.

Borkowski, Jerzy (red.) (1990b). Motor: tygodnik motoryzacyjny, 13.

Borkowski, Jerzy (red.) (1990c). Motor: tygodnik motory zacyjny, 27.

Borkowski, Jerzy (red.) (1990d). Rozmowy FSO i GM. Motor: tygodnik motoryzacyjny, 51, 2.

Borkowski, Jerzy (red.) (1991a). Motor: tygodnik motoryzacyjny, 6.

Borkowski, Jerzy (red.) (1991b). Auto Motor Sport: cotygodniony magazyn motoryzacyjny, 1.

Chmielewski, Grzegorz (1989a). Na tropie wielkiej ropy. Motor: tygodnik motoryzacyjny, 51-52, 4.

Chmielewski, Grzegorz (1989b). Prognoza nieoptymistyczna. Motor: tygodnik motoryzacyjny, $51-52,2$.

Czarski, Ryszard (1965). Kto zajmie się przyszłością motoryzacji indywidualnej. Motor: tygodnik ilustrowany, 27, 1.

Czechowski, Dariusz (1990). Krótka historia długich negocjacji. Motor: tygodnik motoryzacyjny, $51,4$.

Do czytelników (1952). Motor. Tygodnik pracowników transportu samochodowego, 1, 1.

Drexler, Zbigniew (1985). ... wjechałby w klatkę schodowa. Motor: ilustrowany magazyn motoryzacyjny, 11, 6-7.

Dyszy, Jerzy (1988). Zdobywamy kraje nadbałtyckie. Motor: ilustrowany magazyn motoryzacyjny, $38,18$.

Gawuć, Henryk (1989). Zaklęte koło. Motor: tygodnik motoryzacyjny, 51-52, 16-17.

Grzeszak, Adam (1988). Kłopoty z przedpłatami. Motor: ilustrowany magazyn motory racyjny, $38,4$.

Grzeszak, Adam (1989). Historia lubi się powtarzać... Motor: tygodnik motoryzacyjny, 46, 2.

Jankowski, Jerzy (red.) (1977). Motor: ilustrowany magazyn motoryzacyjny, 47, 19.

Jankowski, Jerzy (red.) (1982). Motor: ilustrowany magazyn motoryzacyjny, 1, 1.

Jankowski, Jerzy (red.) (1987). Motor: ilustrowany magasyn motoryzacyjny, 4, 1.

Jankowski, Jerzy (red.) (1988a). Motor: ilustrowany magazyn motoryzacyjny, 9, 1.

Jankowski, Jerzy (red.) (1988b). Motor: ilustrowany magazyn motoryzacyjny, 37.

Jankowski, Jerzy (red.) (1988c). Motor: ilustrowany magasyn motoryzacyjny, 38.

Jankowski, Jerzy (red.) (1988d). Wojciech Jaruzelski w FSO. Motor: ilustrowany magazyn motoryracyjny, 38, 2.

Jankowski, Jerzy (red.) (1989). Motor: ilustrowany magazyn motoryzacyjny, 9, 1.

Karpińska, Henryka (1989). Polowanie na czarownice. Motor: tygodnik motoryzacyjny, 51-52, 5. 
Karpińska, Henryka (1990). Włochy. Motor: tygodnik motoryzacyjny, 27, 16-17.

Kasprzycki, Paweł (red.) (1991). Motor: magazyn motoryzacyjny, 7.

Komu służy samochód w krajach kapitalistycznych (1952). Motor. Tygodnik pracownikón transportu samochodowego, 2, 9.

Kubiak, Stefan (1965). Gordyjski węzeł. Motor: tygodnik ilustrowany, 6, 6-7.

Lange, Ryszard (red.) (1957). Motor: tygodnik ilustrowany, 1.

Lange, Ryszard (red.) (1958a). Motor: tygodnik ilustrowany, 3, 1.

Lange, Ryszard (red.) (1958b). Motor: tygodnik ilustrowany, 9, 15.

Lange, Ryszard (red.) (1959). Motor: tygodnik ilustrowany, 51-52, 1.

Lange, Ryszard (red.) (1960). Motor: tygodnik ilustrowany, 1.

Lange, Ryszard (red.) (1962). Motor: tygodnik ilustrowany, 32.

Leszkowicz, Tomasz (2015). Prasa na gruzach partyjnego koncernu. Likwidacja RSW „Prasa-Ksiqخ̇ka-Ruch”. Pobrany 15 maja 2018, z: https://histmag.org/Prasa-na-gruzypartyjnego-koncernu.-Likwidacja-RSW-Prasa-Ksiazka-Ruch-8099/1

Lubiński, Józef (1991). Najważniejsze zasady i cele polityki PZPR w dziedzinie komunikowania w latach 1948-1971. Kwartalnik. Historii Prasy Polskiej, 30, 2, 119-140.

Marczyński, Antoni (1958). Piękności, które w 1958 zadebiutują na ekranach. Motor: tygodnik ilustrowany, 3, 12-13.

Najhajt, Wiesław (1984). Tak daleko, tak blisko... Jak odejść od reglamentacji? Motor: ilustrowany magasyn motoryzacyjny, 7, 4 .

Olchowik, Liliana 1990. Paskuda w zalewie. Motor: tygodnik motoryzacyjny, 26, 16-17.

Rejewski, Leon (red.) (1962). Motor: tygodnik ilustrowany, 41.

Rejewski, Leon (red.) (1975). Prezentujemy nowy model Motoru. Motor: ilustrowany magazyn motoryzacyjny, 1,1 .

Rejewski, Leon (1965). Kodeks i praktyka. Motor: tygodnik ilustrowany, 2, 1.

Rejewski, Leon (1968). Dorobek, potrzeby, zadania. Motor: tygodnik ilustrowany, 45, 1, 3.

Sędzikowski, Krzysztof (1965). Autostrada słońca z okien polskiego autokaru. Motor: tygodnik ilustrowany, 33, 4.

Sobiecki, Tomasz (1967). Badanie drogowe samochodu FSO Warszawa 203 K. Pobrany 15 lutego 2018, z: https://magazynauto.interia.pl/rozrywka/motor-z-przeszlosci/news-badaniedrogowe-samochodu-fso-warszawa-203-k,nId,2484366

Sobiecki, Tomasz (1983). Nieco bliżej do mety. Motor: ilustrowany magazyn motoryzacyjny, 40, 3.

Szelichowski, Stanisław (red.) (1977). Motor: ilustrowany magazyn motoryzacyjny, 8, 19.

Szelichowski, Stanisław, Tomasz Sobiecki (1965). Po raz trzydziesty czwarty. Motor: tygodnik ilustrowany, 26.

Tumiłowicz, Bronisław (1985). Uciekłeś - znaczy piłeś! Motor: ilustrowany magasynn motoryzacyj$n y, 1,4$. 


\section{Wykaz analizowanych roczników czasopisma "Motor"}

- Warszawa: Wydaw. Komunikacyjne. ISSN 0580-0447:

Motor: Tygodnik pracownikón transportu samochodowego, 1952, 1-36.

Motor: Tygodnik pracownikón transportu samochodowego, 1953, 1-52.

Motor: Tygodnik pracownikón transportu samochodowego, 1954, 1-52.

Motor. Tygodnik ilustrowany, 1956, 1-52.

Motor: tygodnik ilustrowany, 1957, 1-52.

Motor: tygodnik ilustrowany, 1958, 1-51/52

Motor: tygodnik ilustrowany, 1959, 1-51/52

Motor: tygodnik ilustrowany, 1960, 1-51/52.

Motor: tygodnik ilustrowany, 1962, 1-52.

Motor: tygodnik ilustrowany, 1965, 1-51/52

Motor: tygodnik ilustrowany, 1967, 1-52/53.

- Warszawa: Wydaw. Komunikacji i Lączności. ISSN 0580-0447:

Motor: tygodnik ilustrowany, 1968, 1-51/52

Motor: tygodnik ilustrowany, 1970, 1-51/52

Motor: tygodnik ilustrowany, 1972, 1-52/53.

- Warszawa: Młodzieżowa Agencja Wydawnicza RSW „Prasa-Książka-Ruch”.

ISSN 0580-0447:

Motor: ilustrowany magazyn motoryzacyjny, 1975, 1-51/52.

Motor: ilustrowany magazyn motoryzacyjny, 1977, 1-51/52.

Motor: ilustrowany magazyn motoryzacyjny, 1979, 1-51/ 52.

Motor: ilustrowany magazyn motoryzacyjny, 1980, 1-51/52.

Motor: ilustrowany magazyn motory zacyjny, 1982, 1-38.

Motor: ilustrowany magazyn motoryzacyjny, 1983, 1-52

Motor: ilustrowany magasyn motoryzacyjny, 1984, 1-53.

Motor: ilustrowany magazyn motoryzacyjny, 1985, 1-52

Motor: ilustrowany magazyn motoryzacyjny, 1987, 1-52.

Motor: ilustrowany magazyn motoryzacyjny, 1988, 1-52.

Motor: ilustrowany magasyn motoryzacyjny, 1989, 1-51/52

Motor: tygodnik motoryzacyjny, 1990, 1-52

- Warszawa: Labor. ISSN 0580-0447

Motor: magazyn motoryzacyjny, 1991, 1-10. 


\title{
"Motor" as the oldest contemporary Polish automotive magazine Analysis for the years 1952-1991
}

\begin{abstract}
Motor" weekly is the oldest contemporary Polish automotive magazine. The periodical in over 65 years of existence has permanently inscribed in the canon of the Polish automotive press. The article describes the outline of "Motor" weekly presence in the press market since the release of the first issue in 1952 until taking over by the new publisher at the end of 1991. Due to the modest number of scientific publications on automotive literature, the author primarily examined the year's issues of "Motor". The research part was supplemented by an attempt at theoretical analysis and assessment of the impact of the political and economic situation in Poland in the years 1952-1991 on the content and the situation of the magazine on the press market.
\end{abstract}

KEYWORDS: automotive press, the press of the PRL, Polish automotive magazines, "Motor" weekly, history, Polish People's Republic, political transformation. 